\title{
Penerapan Group Investigation untuk Meningkatkan Pemahaman Matematika Siswa Kelas VI pada Materi Bangun Ruang di MI GUPPI Ringinanom Udanawu
}

\author{
Fathul Niam $^{(1)}$ \\ ${ }^{1}$ Program Studi Pendidikan Guru SD Universitas Nahdlatul Ulama Blitar \\ Email: ${ }^{1}$ masniam1116@gmail.com
}

\begin{tabular}{l}
\hline Tersedia Online di \\
\hline http://www.jurnal.unublitar.ac.id/ \\
index.php/briliant
\end{tabular}

Sejarah Artikel

Diterima pada 9 Agustus 2018

Disetuji pada 9 Agustus 2018

Dipublikasikan pada 13 Agustus

2018 Hal. 349-353

\begin{tabular}{l}
\hline Kata Kunci: \\
group investigation, pemahaman \\
matematika, bangun ruang.
\end{tabular}

DOI:

http://dx.doi.org/10.28926/briliant .v3i3.222

\begin{abstract}
Abstrak: Penelitian ini dimaksudkan untuk mendiskripsikan penerapan group investigation yang dapat meningkatkan pemahaman matematika siswa kelas VI pada materi bangun ruang. Menggunakan pendekatan penelitian tindakan kelas (PTK), penelitian yang dilaksanakan di MI GUPPI Ringinanom Udanawu Blitar ini diikuti oleh 30 siswa yang terdiri dari 10 siswa laki-laki dan 20 siswa perempuan. Hasil dari dua siklus pembelajaran menunjukkan bahwa tindak pembelajaran dengan group investigation yang mampu meningkatkan pemahaman matematika siswa adalah: (1) guru selalu mengadakan tanya jawab tentang materi prasyarat yang dimiliki siswa sampai pemahaman mereka tentang materi prasyarat dipandang memadai untuk melakukan investigasi, (2) guru harus selalu berkeliling ke setiap kelompok dan membantu siswa yang mengalami kesulitan dalam memahami masalah secara individual, (3) guru menata posisi tempat duduk siswa dalam setiap pertemuan.
\end{abstract}

Selama bertahun-tahun, pembelajaran matematika dikelas lebih banyak menekankan kepada pengembangan kemampuan prosedural, dicirikan dengan "talk and chalk" yang berfokus pada latihan soal (drill) dan lebih mementingkan hasil daripada proses (Yuwono,2009). Pembelajaran yang demikian ini ternyata mengakibatkan siswa kurang memahami matematika.

Mengingat pembelajaran kooperatif memiliki peluang untuk meningkatkan kualitas proses pembelajaran dan meningkatkan pemahaman (Slavin, 2005), pembelajaran matematika di MI GUPPI Ringinanom Udanawu juga telah mencoba menerapkan pembelajaran kooperatif. Akan tetapi, hasil sementara menunjukkan bahwa pemahaman siswa di MI GUPPI Ringinanom Udanawu Blitar masih belum meningkat secara signifikan. Nilai ulangan harian matematika siswa kelas VIII masih rendah. Sebanyak 55\% siswa atau 16 siswa dari 30 siswa di kelas tersebut mendapatkan nilai di bawah 75 . Hasil observasi dan wawancara peneliti dengan guru matematika menunjukkan bahwa ketika pembelajaran kooperatif berlangsung sekalipun, siswa masih kurang aktif terlibat dalam pembelajaran. Mereka masih sering "ngobrol" sendiri dengan temannya, dan tidak memperhatikan pembelajaran. Ini mendorong peneliti untuk menemukan model pembelajaran kooperatif yang lebih baik yang mampu meningkatkan pemahaman siswa.

Menurut Sharan \& Sharan (1989), group investigation merupakan media organisasi yang efektif untuk membimbing dan mendorong siswa dalam belajar. 
Dengan group investigation, siswa aktif berbagi dalam setiap kegiatan di dalam kelas.Menurut hasil penelitian, pembelajaran kooperatif group investigation sangat efektif digunakan oleh guru dalam pembelajaran karena dapat membuat situasi belajar siswa kearah yang lebih baik (Tsoi, Goh, \& Chia, 2004). Hasil akademik kelas yang dibelajarkan dengan model group investigation lebih baik dibanding dengan hasil belajar di kelas control. Nilai post-test kelas group investigation lebih baik bila dibandingkan dengan kelas control (Akcay \& Doymus, 2012). Prinsipnya, group investigation memiliki peluang untuk meningkatkan pemahaman siswa (Mahsup, 2010; Falupi, 2011; Masjudin (2011).

Pembelajaran dengan model group investigation belum pernah diterapkan di MI GUPPI Ringinanom Udanawu Blitar. Dengan kultur dan kondisi kelas yang berbeda dengan kelas-kelas yang digunakan oleh para peneliti sebelumnya, penerapan group investigation di MI GUPPI Ringinanom Udanawu tentu masih belum bisa dipastikan keberhasilannya. Penerapan group investigation yang mengikuti cara yang diterapkan di tempat lain mungkin tidak bisa sesukses di tempat semula. Sangat mungkin diperlukan penyesuaian tindak pembelajaran.

\section{METODE}

Penelitian ini menggunakan pendekatan Penelitian Tindakan Kelas (PTK) dengan prosedur sebagai berikut: (1) perencanaan (planning ), (2) pelaksanaan tindakan (action ), (3) observasi (observasi), (4) refleksi (reflection). Penelitian dilakukan di kelas VI MI GUPPI Ringinanom Udanawu Blitar, dimana sebanyak 30 siswa, terdiri dari 20 siswa wanita dan 10 siswa pria, dengan kemampuan akademik yang heterogen terlibat di dalam penelitian ini. Peneliti 1 pada penelitian ini bertindak sebagai guru dan sekaligus pelaksana tindakan di kelas.

Data yang dikumpulkan dalam penelitian ini, adalah data tentang: (1) pemahaman matematika siswa dan (2) tindakan guru selama melaksanakan pembelajaran group investigation. Data pemahaman siswa diperoleh dari skor hasil tes akhir siklus dan skor penyelesaian soal di LKS yang ditulis dalam lembar investigasi.Data tindakan guru dalam pembelajaran ini ada dua macam yaitu: data kuantitatif dan data kualitatif. Data kuantitatif digunakan untuk melihat kesesuaian antara praktik pembelajaran yang dilakukan guru dengan rencana pembelajaran yang ditetapkan. Data kualitatif untuk mendeskripsikan tindakan yang dilakukan guru selama proses pembelajaran dilaksanakan.

Instrumen untuk pengumpulan data dalam penelitian ini telah divalidasi oleh pakar pendidikan matematika (guru matematika yang telah mengajar minimal 5 tahun). Di samping itu, untuk pengumpulan data, peneliti juga menggunakan lembar wawancara siswa untuk menggali informasi tentang pemahaman matematika siswa.Catatan lapangan juga dibuat oleh peneliti untuk keperluan triangulasi data.

Data yang telah dikumpulkan dianalisis melalui dua cara sebagai berikut: (1) analisis data kuantitatif, dan (2) analisis data kualitatif. Analisis data kuantitatif dimaksudkan untuk memastikan penerapan pembelajaran Group Investigation dalam penelitian sudah sesuai dengan rencana atau tidak.Selain itu analisis data kuantitatif juga untuk melihat apakah indikator keberhasilan pembelajaran masih belum berhasil dan perlu dilanjutkan ke siklus berikutnya atau tidak.

350 BRILIANT: Jurnal Riset dan Konseptual

Volume 3 Nomor 3, Agustus 2018 
Analisis data kualitatif yang dilakukan dalam penelitian ini adalah analisis dalam rangka untuk mengidentitikasi tindakan pembelajaran yang diduga sebagai penyebab gagal atau berhasilnya tindakan guru dalam meningkatkan pemahaman matematika siswa.Analisis data kualitatif ini dilakukan dengan memilah dan memilih data-data yang sesuai atau tidak, sesuai kebutuhan, mengklasifikasikan, menyajikan, dan menyimpulkan.

\section{HASIL}

Setelah dilakukan tiga kali pembelajaran di siklus pertama, peneliti mengadakan tes untuk mengukur pemahaman siswa. Hasil tes menunjukkan $67,5 \%$ siswa memperoleh skor sedikitnya 75 . Persentase ini masih di bawah dari kriteria keberhasilan tindakan yang mematok $75 \%$ siswa memperoleh skor minimal 75.Dengan demikian, tindak pembelajaran pada siklus I dianggap tidak berhasil, dan karenanya perlu dilakukan perubahan.

Pada siklus kedua, yang juga berlangsung selama tiga kali pertemuan, peneliti 1 melakukan perubahan-perubahan tindakan. Kalau semula penggalian materi prasyarat dilakukan hanya sepintas lalu, pada siklus kedua penggalian materi prasyarat dilakukan dengan lebih intensif.Tanya jawab tentang penguasaan materi prasyarat dilakukan secara lebih intensif dengan maksud agar siswa lebih percaya diri dalam menghadapi masalah. Di samping itu, peneliti 1 juga lebih sering berkeliling kelas dan mengunjungi setiap kelompok sambil memantau pekerjaan siswa.Manakala ada siswa yang mengalami kesulitan, peneliti 1 dengan segera memberikan bantuan yang diperlukan sehingga siswa bisa lebih focus mengerjakan kegiatan belajarnya.Terakhir, Peneliti 1 juga sering memodifikasi posisi tempat duduk siswa.Posisi tempat duduk siswa tidak dibuat statis agar unsur kejenuhan bisa dieliminasi.

Perubahan-perubahan tindakan yang dilakukan oleh peneliti 1 ini ternyata memberikan dampak yang positif terhadap hasil belajar siswa.Hasil tes pemahaman menunjukkan $80 \%$ siswa telah memperoleh sekor minimal 75.Karena itu, tindakan dalam siklus kedua ini dianggap sudah berhasil, dan penelitian tidak perlu diteruskan lagi.

\section{PEMBAHASAN}

Di atas telah dikemukakan bahwa tindak pembelajaran dalam penerapan pembelajaran dengan group investigation yang mampu meningkatkan pemahaman siswa tentang materi geometri adalah penggalian secara intensif materi prasyarat.Siswa harus dibantu memahami materi ajar, apalagi bila materi ajar tersebut merupakan hal yang diperlukan dalam kegiatan investigasi.Ini sesuai dengan As'ari (2011)yang menyatakan bahwa pembelajaran harus diarahkan untuk membantu siswa memahami materi ajar.Untuk menghadapi masalah, siswa perlu dibimbing dengan menyiapkan materi prasyarat yang diperlukan.Ini sesuai dengan pendapat Mulyasa (2005) yang menyatakan perlunya bimbingan kepada siswa, baik untuk mendapatkan pengalaman maupun untuk membentuk kompetensi yang diinginkan.

Di dalam penerapan group investigation ini, peneliti 1 berkeliling kesetiap kelompok, menanyakan langsung kesulitan yang dialami, terutama dalam menuliskan hasil investigasi serta dalam membuat kesimpulan, dan memberikan bantuan yang diperlukan.Ini sesuai dengan pendapat Isjoni (2011) yang 
menyatakan perlunya guru memantau, mengarahkan, dan membimbing siswa baik secara individu maupun secara kelompok.

Pengubahan posisi tempat duduk kelompok setiap kali pertemuan, dimana setiap kelompok mempunyai kesempatan yang sama untuk duduk didepan ditengah atau dibelakang, juga membawa dampak yang positif terhadap pemahaman siswa. Dengan pengaturan seperti ini, setiap siswa merasa diperhatikan, dan tidak merasa bosan dalam megikuti pembelajaran. Akibatnya, mereka fokus dalam mengerjakan tugasnya, dan pemahaman mereka pun akan meningkat. Ini sesuai dengan pendapat Lotfy (2012) yang menyatakan bahwa pengaturan tempat duduk dapat mempengaruhi siswa dalam melaksanakan tugasnya. Siswa juga akan lebih fokus dan penuh perhatian sesuai dengan tugas yang diharapkan (Faize\&Dahar, 2011).

\section{KESIMPULAN}

Secara garis besar dapat disimpulkan bahwa tindak pembelajaran group investigation yang mampu meningkatkan pemahaman konsep geometri siswa MI GUPPI Ringinanom Udanawu Blitar adalah tindak pembelajaran sebagaimana penerapan group investigation pada umumnya. Akan tetapi, untuk memberikan pemahaman yang lebih baik, guru harus memperhatikan tiga hal berikut: (1) sebelum melaksanakan investigasi, guru harus meyakinkan agar penguasaan materi prasyarat betul-betul tinggi. Penggunaan strategi Tanya jawab perlu dilakukan secara intensif sampai guru merasa yakin bahwa siswa siap melakukan investigasi, (2) selama proses investigasi dan kerja kelompok untuk menuliskan hasil invesitigasi mereka, guru harus aktif berkeliling, memantau kemajuan kerja setiap kelompok, dan memberikan bantuan yang diperlukan kepada mereka yang mengalami kesulitan, (3) posisi tempat duduk siswa perlu diganti-ganti. Jika pada pertemuan pertama, kelompok A berada di depan, maka pertemuan berikutnya, kelompok A perlu dipindah ke bagian tengah, dan pada pertemuan yang berikutnya lagi, mereka perlu dipindah ke bagian belakang, sehingga mereka semua terkesan memperoleh perhatian dan diperlakukan secara adil.

\section{SARAN}

Berdasarkan simpulan di atas, para guru yang ingin menerapkan pembelajaran group investigation hendaknya memperhatikan betul tiga hal di atas. Pertama, sebelum siswa diturunkan untuk melakukan investigasi, guru harus meyakinkan bahwa mereka memiliki bekal materi yang memadai. Kedua, guru harus aktif berkeliling, memantau kemajuan belajar siswanya, dan memberikan bantuan yang diperlukan sesegera mungkin. Terakhir, guru harus berupaya agar dikesankan memberikan perhatian yang adil kepada siswanya. Pengaturan tempat duduk adalah salah satu di antaranya. Tetapi, guru juga perlu mencari strategi yang lain yang menjamin rasa nyaman karena mendapatkan perhatian yang sama dari gurunya. Selanjutnya, para peneliti lain perlu menyadari bahwa di dalam penelitian ini, pengukuran pemahaman siswa dilakukan hanya satu kali saja, yaitu di ujung siklus pembelajaran. Tidak ada pengukuran yang dilakukan setelah tindak pembelajaran ini berlalu beberapa lama. Karenanya, tidak ada jaminan apakah pemahaman yang diperoleh di akhir siklus 2 akan tetap bagus setelah berlalunya waktu. Untuk itu, perlu dilakukan penelitian serupa dengan 
pengukuran hasil pemahaman dilaksanakan satu kali segera setelah akhir siklus kedua, dan satu kali lagi setelah siklus kedua berlalu beberapa lama.

\section{DAFTAR RUJUKAN}

As'ari, A.R. 2011. Membangun Karakter Pebelajar Unggulan Melalui Pembelajaran Matematika.Makalah disampaikan dalam Seminar Nasional Matematika dan PendidikanMatematika tanggal 21-23 Juli 2011 di FMIPA UNY.

Akcay, N.O \& Doymus K. 2012. The Effects of Group Investigation and Cooperative Learning Tecniques Applied in Teaching Force and Motion Subjects on Student' Academic Achievements. Jurnal Internasional, 2(1). http://www.ebad-jesr.comimagesMAKALE_ARSIVC2_S1makalel er2\%20(1)\%20-\%2007.pdf.

Falupi, L. 2011, Penerapan Group Investigation (GI) untuk Memahamkan Operasi Pecahan Pada Siswa Kelas VII A di SMP Negeri 4 Kepanjen dengan Menggunakan Pita Pecahan . Tesis tidak diterbitkan : PPs UM.

Isjoni. 2011. Cooperative Learning. Bandung: Alfabeta.

Lotfy, N. 2012. Seating Arrangement and Cooperative Learning Activities:Students'On-task/ Off-task Participation in EFL Classrooms. Thesis: The American University in Cairo.

Mahsup. 2010. Penerapan Strategi Investigasi untuk meningkatkan pemahaman tentang sistem persamaan linier (SPL) Dua Variabel di SMP Negeri Kepanjen Malang. Tesis tidak diterbitkan : PPs UM.

Masjudin. 2011. Pembelajaran Kooperatif Investigasi untuk memahamkan siswa pada materi Barisan dan Deret di kelas XII IPA SMAN 1 Batu. Tesis tidak diterbitkan : PPs UM.

Mulyasa. 2005. Menjadi Guru Profesional: Menciptakan Pembelajaran Kreatif dan Menyenangkan. Bandung: Remaja Rosdakarya.

Slavin, R.E. 2005. Cooperative Learning: Theory, Research and Practice. Penerjemah : Nurulita Y. Bandung: Nusa Media.

Sharan.Y., \& Sharan, S. 1989/1990. Group Investigation Expands Cooperative Learning. (Online), (http://www.ascd.orgASCDpdfjournalsed_leadel_ 198912_sharan.pdf).

Tsoi, M.F., Goh, N. K., \& Chia, L. S. 2004. Using Group Investigation For Chemistry In Teacher Education. Forum Asia-pasifik Vol.5. https://www.ied.edu.hk/apfslst/v5_issue1/tsoimt/.pdf.

Yuwono, I. 2009. Membumikan Pembelajaran Matematika di Sekolah. Pidato pengukuhan Guru Besar dalam bidang Pend. Matematika pada FPMIPA disampaikan pada Sidang Terbuka Senat UM tanggal 5 November 2009. 